\title{
INTEGRATION OF MACROECONOMIC VARIABLES IN THE ANALYSIS OF CREDIT RISK AND THE IMPACT ON THE RATE OF RETURN OF COMPANIES AND THE DEGREE OF CORPORATE INDEBTEDNESS
}

\author{
Luminiţa Gabriela ISTRATE ${ }^{* a}$
}

${ }^{a}$ Bucharest University of Economic Studies, Romania

DOI: $10.24818 / \mathrm{IMC} / 2020 / 01.15$

\begin{abstract}
The credit risk management is an important component of the activity of credit institutions, and an increased supervision is mainly done through credit portfolios.

The research offers a perspective on the quantification of non-performing loan rate within the Romanian banking system. The results obtained showed that the strongest impact is that of the EUR/RON exchange rate, however, neither the influence of the impaired receivable rate in the total assets of credit institutions nor the monetary policy interest rate are to be neglected.

The presented model aims to define the relationship between the quality of credit portfolios and the macroeconomic environment in Romania. In this respect, 25 annual observations were analysed, the reviewed period of time being 2015 - 2019.
\end{abstract}

KEYWORDS: degree of indebtedness, exchange rate, interest rate, non-performing loan rate, risk

\section{INTRODUCTION}

Given the macroeconomic evolution in recent years and the impact on the credit portfolios of financial institutions, is has been noticed an increased interest in the risk management and in early warning systems. Risk management is an important element in the activity of the credit institutions, banks giving a high importance to the quality of the loan portfolios to the detriment of their volumes. In the 2005 - 2008 boom years, the financial institutions adopted a policy of aggressive growth of the market share, based on providing a simplistic system of analysis of loans and on products that encouraged the speculative transactions.

This study aims to define a framework for highlighting some macroeconomic influences on the nonperforming loan rate. The paper addresses two main aspects: the determinants of the nonperforming loan rate and the influence of the economic environment. In order to understand the impact of non-performing loans on the share capital of financial institutions, the paper analyses the macroeconomic conditions through the following variables: the rate of return on basic activity, the monetary policy interest rate, the degree of corporate indebtedness, the EUR/RON exchange rate. In this sense, a number of 25 observations from the period 2015-2019 were tested, the research methodology being based on the analysis and interpretation of statistical results.

The Romanian market was selected for analysis because the economy is not in the Euro area, but it is an emerging economy depending on the external investments, and the local market has shown an increase in the volume of loans during the periods of economic growth.

The empirical analysis aims to explain the influence that the independent variables have on the nonperforming loan rate (the dependent variable). Also, the purpose of the paper is to obtain a functional form for determining the future values that can be recorded for the non-performing loan rate.

\footnotetext{
* Corresponding author. E-mail address: istrate luminita@yahoo.com
} 


\section{MANUSCRIPT}

\subsection{Literature Review}

Granting loans also involves risks, because the bank can never be sure that the company or individual will repay the funds within the agreed time. Thus, mismanagement of risk can lead to non-performing loans (NPLs) when there are indications of the likelihood that the borrower will not repay the loan due to financial difficulties or when more than 90 days have passed without the borrower having paid the agreed instalments.

The scholarly literature focused on explaining the influence of macroeconomic performance on credit risk and the non-performing loan rate. A detailed picture of this topic was presented by the economists Dash \& Kabra (2010).

GDP growth, exchange rate appreciation, interest income and the value of interbank loans are variables that best explain the delinquent rate for African countries (Fofack, 2005).

In order to quantify the impact of the macroeconomic conditions on the repayment capacity of the debtors, methodological solutions were used which are based on multiplying the set of explanatory variables for the scoring model with aggregated indicators (Bunn \& Redwood, 2003). Also, the connection functions can be used to model the dynamics of some items of the debtor's balance sheet, using equations, including macroeconomic variables (Bunn \& Redwood, 2003).

Mcwayizeni Thwala (2016) highlighted that macroeconomic variables have a significant impact on the non-performing loan ratio in the case of developing countries, but do not have a significant influence in the case of developed economies.

Figlewski et al. (2012) highlighted the significant impact of macroeconomic variables on the solvency of firms, grouping risk factors according to the general macroeconomic conditions (unemployment rate, inflation), the direction in which the economy evolves (GDP growth, consumer behaviour) and the conditions in international markets (interest rate, listing/delisting).

On the other hand, Vasiliki Makri and Konstantinos Papadatos (2016) made a point as to the fact that the non-repayment of overdue loans seems to be closely linked to the macroeconomic environment, and Makri et al. (2014), analysing non-performing loans in the Euro area, concluded that macroeconomic variables obviously influence the rate of non-performing loans.

The study carried out by Klein (2013) analyses the non-performing loan rate in the period from 1998 to 2011 in 16 countries located in Central and South-Eastern Europe (CESSE). The results of his research showed that the level of non-performing loans can be determined by both macroeconomic conditions and by conditions specific to the banking sector, although the latter are considered having a relatively low explanatory power. While the delinquent rate is influenced by the macroeconomic conditions (increase in GDP, unemployment, inflation rate), the analysis also indicates that there are strong effects of the banking system for the real economy, thus suggesting that the high non-performing loan rate which many countries in CESSE are facing is inversely affecting the pace of the economic recovery.

In 2014, Skala studied the factors influencing lending policy for a number of Polish commercial banks, reaching the conclusion that macroeconomic factors have a strong impact on non-performing loans, while Alessi et al. (2014) found the fact that provisions for loan impairment are positively associated with the non-performing loan ratio and the loans/assets ratio.

While analysing the non-performing loans broke down by different categories (consumer, mortgage, corporate) for the 9 largest Greek banks, the study by Louzis et al. (2010) showed that the non-performance is explained by the quality of the management and the macroeconomic conditions. Also, the study highlighted the positive correlation between the non-performing loan rate and the real crediting rates, the poor management and the consistent difference between operating expenses and income. Similar results were also obtained by Espinosa and Prasad (2010) in a study regarding the non-performing loans and their macroeconomic effects. The authors 
explained and forecasted the credit risk rate at the macro level, using the aggregate values of the credit risk, regarding the total outstanding credits in the economy.

Vitor Castro (2013), using a panel data model, concluded that credit risk increases with decreasing GDP and stock prices and decreases with the appreciation of the exchange rate and the increase in the unemployment rate.

In a study on the Finnish economy, Virolainen (2004) applies dynamic models for the credit risk, using macroeconomic variables such as: the interest rate on the interbank market with a maturity of up to one year, the economic growth and the degree of corporate indebtedness.

As regards the classification of non-performing loans, the International Monetary Fund recommends that loans be classified in such a way if they have arrears of more than 90 days. Also included in this category are loans with a debt service of less than 90 days when there is a clear indication in this regard (bankruptcy, insolvency). Moreover, Moody's rating agency defines nonperforming loans as assets that fall within the following criteria:

- they record arrears of at least 60 days in the principal amount and interest in the case of consumer loans granted to natural persons;

- they record arrears of at least 90 days in the principal amount and interest in the case of commercial loans and leasing;

- $\quad$ any credit for which there are signals of non-performance.

Derbali's study (2011) highlighted a positive association between inflation and the rate of return of the bank. High interest rates are associated with a high rate of inflation, but if banks do not anticipate rising inflation by adjusting the interest rate, the banks' profitability may be adversely affected.

In 2014, Buch et al., analysing the relation between macroeconomic factors and lending policy in the US, concluded that macroeconomic shocks affect banks depending on their size, capitalization and liquidity.

Arestis and Jia (2019) examined the vulnerability of Chinese commercial banks to changing macroeconomic conditions by using a macroeconomic stress-test. The authors focused on how changes in the dynamics of real estate market variables influence credit risk for the entire Chinese banking system. The results of the study show that the Chinese banking system is relatively stable and that the Central Bank of China is able to monitor the credit risks of commercial banks using appropriate loan policies.

The empirical evaluation of the significant macroeconomic indicators that influence the credit risk in the high-income countries shows that the development of the industry sectors and exports are the main factors that determine high-performance loans in the high-income countries (Koju et al., 2019). The results recommend the adoption of an expansionary tax policy to stimulate per capita income and productivity. The study also recommends that the Government increases the productivity of export-oriented industries and adopts a series of economic policies designed to control non-payment risks.

In 2018, Zheng et al. pointed out that the return on capital and the size of the bank are inversely associated with the credit risk, while the net interest margin is directly proportional to this risk, while Johnson, A. et al. (2017) studied the relationship between the macroeconomic factors and the financial health of companies in the agricultural sector. The latter concluded that macroeconomic variables certainly influence the financial health of agricultural companies and suggest that their creditors should focus on macroeconomic variables in credit risk models.

In order to quantify the credit risk, the National Bank of Romania used the credit risk rate and, later, introduced the non-performing loan rate, which has been modified over time, currently having the definition agreed by the European Banking Authority. Two Romanian authors, Moinescu and Codirlașu (2013), extended their research on non-performing loans, referring to the macroeconomic imbalance noticed in the case of variations in the private sector. The research was carried out for ten countries in the European Union, the values being analysed using the annual data regressions, covering a period of 12 years $(2000-2011)$. 


\subsection{Sample and Data Collection}

This study assesses the impact of macroeconomic indicators on the deterioration of the loan portfolio.

The analysis concerns data with annual frequency from the period 2015 to 2019, available on the National Bank of Romania's website.

For the purpose of the research, we used:

- Dependent variable - Y, "non-performing loan rate" according to the definition by EBA (European Banking Authority), as it appears under the aggregate indicators regarding the credit institutions listed on the National Bank of Romania's website, expressed as a ratio between the non-performing exposures of loans and advances and the exposures of loans and advances. Exposures are considered to be non-performing and the debtor is considered insolvent when: 1) are significant exposures that are more than 90 days past due; 2) it is considered that, in the absence of the execution of the real guarantee, it is unlikely that the debtor will pay in full the obligations from the loans, regardless of the existence of any outstanding amount or the number of days of payment delay.

- Independent variables:

- Rate of return on basic activity $-\mathrm{X}_{1}$

- Monetary policy interest rate $-\mathrm{X}_{2}$

- Impaired receivable rate in the total assets of credit institutions $-\mathrm{X}_{3}$

- EUR/RON exchange rate $-\mathrm{X}_{4}$

The data subject to the analysis are presented in Table no.1.

Table 1. Database with the values of the main variables

\begin{tabular}{|c|c|c|c|c|c|}
\hline Year & $\begin{array}{c}\text { Rate of } \\
\text { return on } \\
\text { basic activity }\end{array}$ & $\begin{array}{c}\text { Monetary } \\
\text { policy } \\
\text { interest rate }\end{array}$ & $\begin{array}{c}\text { Impaired } \\
\text { receivable rate in } \\
\text { the total assets of } \\
\text { credit institutions }\end{array}$ & $\begin{array}{c}\text { EUR/RON } \\
\text { exchange } \\
\text { rate }\end{array}$ & $\begin{array}{c}\text { Non-performing } \\
\text { loan rate according } \\
\text { to the definition by } \\
\text { EBA }\end{array}$ \\
\hline 2015 & 1.7131 & 0.0175 & 0.0385 & 4.5245 & $\mathbf{Y}$ \\
\hline 2016 & 1.8857 & 0.0175 & 0.0267 & 4.5411 & 0.1351 \\
\hline 2017 & 1.8162 & 0.0175 & 0.0164 & 4.6597 & 0.0962 \\
\hline 2018 & 1.8807 & 0.0250 & 0.0196 & 4.6639 & 0.0641 \\
\hline 2019 & 1.8544 & 0.0250 & 0.0167 & 4.7793 & 0.0496 \\
\hline
\end{tabular}

Source: http://www.bnr.ro

It is envisaged that the relationship between the selected variables and the degree of indebtedness will be clear and economically viable, respectively the relationship between each of the variables: the rate of return on basic activity and the non-performing loan rate will be inversely proportional, respectively an increase in this indicator to determine a reduction in the non-performing loan rate, while the relationship between the monetary policy interest rate, the impaired receivable rate in the total assets of credit institutions, the EUR/RON exchange rate and the non-performing loan rate will be directly proportional, an increase in these indicators involving a higher non-performing loan rate.

\subsection{Data Analysis}

In order to study the impact of the evolution of macroeconomic indicators on the non-performing loan rate, equations were used to determine the credit risk based on the variables under research.

Data analysis and research results were obtained with the help of the Excel software package, the econometric analysis being performed on logarithmic series to facilitate the interpretation of the results. 


\section{Hypothesis:}

The research starts from the hypothesis: "Can credit risk be anticipated depending on the evolution of macroeconomic variables?"

The coefficient of the independent variable shows how much the dependent variable $Y_{t}$ changes when the independent variable $\mathrm{X}_{\mathrm{jt}}$ changes with one unit, provided that the other independent variables remain constant.

For the purpose of the analysis, empirical correlations were made between the variables, in order to reflect the degree of influence of each independent variable on the dependent variable.

The correlation matrix of the analysed variables (Table 2) shows that the high values of the nonperforming loan rate $(\mathrm{Y})$ are associated with an increase in the impaired receivable rate in the total assets of credit institutions $\left(\mathrm{X}_{3}\right)$, a fact evidenced by the positive value of the correlation between the two variables.

On the other hand, the negative values of the correlation between the non-performing loan rate (Y) and the rate of return on basic activity $\left(\mathrm{X}_{1}\right)$, the monetary policy interest rate $\left(\mathrm{X}_{2}\right)$ and the EUR/RON exchange rate $\left(\mathrm{X}_{4}\right)$ show that the reduction in the independent variables is associated with a low non-performing loan rate.

Table 2. Correlation matrix of the analysed variables

\begin{tabular}{|l|c|l|c|c|c|}
\hline & $\begin{array}{c}\text { Rate of } \\
\text { return on } \\
\text { basic activity } \\
\text { policy interest } \\
\text { rate }\end{array}$ & $\begin{array}{l}\text { Impaired } \\
\text { receivable } \\
\text { rate in the } \\
\text { total assets of } \\
\text { credit } \\
\text { institutions }\end{array}$ & $\begin{array}{c}\text { EUR/RON } \\
\text { exchange } \\
\text { rate }\end{array}$ & $\begin{array}{c}\text { Non- } \\
\text { performing } \\
\text { loan rate } \\
\text { according } \\
\text { to the } \\
\text { definition } \\
\text { by EBA }\end{array}$ \\
\hline $\begin{array}{l}\text { Rate of return } \\
\text { on basic activity }\end{array}$ & 1 & 1 & & & \\
\hline $\begin{array}{l}\text { Monetary policy } \\
\text { interest rate }\end{array}$ & 0.483079991 & & & & \\
\hline $\begin{array}{l}\text { Impaired } \\
\text { receivable rate } \\
\text { in the total } \\
\text { assets of credit } \\
\text { institutions }\end{array}$ & -0.623437627 & -0.527063461 & & & \\
\hline $\begin{array}{l}\text { EUR/RON } \\
\text { exchange rate }\end{array}$ & 0.427870436 & 0.771039964 & -0.867377353 & & \\
\hline $\begin{array}{l}\text { Non-performing } \\
\text { loan rate } \\
\text { according to the } \\
\text { definition by } \\
\text { EBA }\end{array}$ & -0.646259343 & -0.82885137 & 0.910898947 & 0.950536267 & 1 \\
\hline
\end{tabular}

Source: author processing

The estimation of the regression model in Excel highlighted the multiple correlations between the variables, which shows that there is a very strong relationship between the non-performing credit ratio and the macroeconomic variables under analysis (Table 03 ). 


\begin{tabular}{|l|c|c|c|c|}
\hline \hline \multicolumn{5}{|c|}{ Table 3. Estimation of the regression model } \\
\hline & $\begin{array}{c}\text { Rate of return } \\
\text { on basic } \\
\text { activity } \\
\text { policy interest } \\
\text { rate }\end{array}$ & $\begin{array}{c}\text { Monetary } \\
\text { receivable rate } \\
\text { in the total } \\
\text { assets of credit } \\
\text { institutions }\end{array}$ & $\begin{array}{c}\text { EUR/RON } \\
\text { exchange rate }\end{array}$ \\
\hline SUMMARY OUTPUT & \begin{tabular}{c} 
Impaired \\
\hline Regression Statistics
\end{tabular} & \multicolumn{5}{|l|}{} \\
\hline Multiple R & 0.646259343 & 0.82885137 & 0.910898947 & 0.950536267 \\
\hline R Square & 0.417651138 & 0.686994593 & 0.829736892 & 0.903519195 \\
\hline Adjusted R Square & 0.223534851 & 0.582659458 & 0.772982523 & 0.871358926 \\
\hline Standard Error & 0.42971221 & 0.315037316 & 0.232351969 & 0.174906737 \\
\hline Observations & 5 & 5 & 5 & 5 \\
\hline
\end{tabular}

Source: author processing

By analysing the obtained results, we notice that the non-performing loan rate is more than $90 \%$ influenced by the variation in the EUR/RON exchange rate $(\mathrm{R}$ Square $=0.903519195)$. A significant influence on the non-performing loan rate is also that of the impaired receivable rate in the total assets of credit institutions $(82.97 \%)$, while the rate of return on basic activity and the monetary policy interest rate influence the non-performing loan rate to a lesser extent $(41.76 \%$ respectively $68.70 \%$ ).

The values of the statistical tests highlight the econometric performance of the obtained model, and the data set used allows the verification of the correlation of the coefficients and observes the significance threshold (the probability associated with the $t$ test is lower than the most restrictive level of relevance of $1 \%$, and the probability associated with the $F$ test shows that at least one of the regression coefficients is statistically significant).

Next, we performed the analysis of the data series using the Excel software to determine the correlation between the non-performing loan rate and the independent variables under analysis, the result of the analysis being presented in Table 4.

Table 4. Research results in relation to the independent variables

\begin{tabular}{|l|c|c|}
\hline \multicolumn{1}{|c|}{ Variables under analysis } & Coefficient & Std. Error \\
\hline Intercept & 2.68502272 & 5.442352668 \\
\hline Rate of return on basic activity & -0.78041753 & 3.291223793 \\
\hline Monetary policy interest rate & -0.974224854 & 0.806303924 \\
\hline $\begin{array}{l}\text { Impaired receivable rate in the total assets of credit } \\
\text { institutions }\end{array}$ & 0.683501543 & 0.320573015 \\
\hline EUR/RON exchange rate & -0.96269041 & 3.90445902 \\
\hline
\end{tabular}

Source: author processing

Thus, the estimated model is the following:

$$
Y=2.68502272-0.78041753 * X_{1}-0.974224854 * X_{2}+0.683501543 * X_{3}-0.96269041 * X_{4}
$$

Given that the dependent variable and the independent variables are expressed in natural logarithms, the coefficients of the independent variables show how much the dependent variable changes with 1 percent change in the independent variables. Thus, an increase of $1 \%$ in the rate of return on basic activity will lead to a decrease in the non-performing loan rate by $78.04 \%$. Also, the 1 percent increase in the impaired receivable rate in the total assets of credit institutions will determine the increase in the non-performing loan rate by $68.35 \%$, while reducing the monetary policy interest 
rate and the exchange rate will cause the decrease in the non-performing loan rate by $97.42 \%$ and $96.27 \%$ respectively.

An important motivation in the choice of variables is related to their representativeness, since they illustrate the financial market (the rate of return on basic activity, the monetary policy interest rate, the impaired receivable rate in the total assets of credit institutions, the EUR/RON exchange rate), as well as to the fact that it illustrates the health of the financial system (the non-performing loan rate).

The data mentioned in this study were collected from the statistical reports of the National Bank of Romania, and the statistical tests and analyses performed are in the possession of the author, being available for reference.

\section{CONCLUSIONS}

The credit risk is one of the most important risks a bank is facing, which is why in recent years there has been a focus on adopting banking business models, in order to allow financial institutions to develop an effective risk assessment framework, without jeopardizing the rate of return.

The econometric results of this study suggest that the monetary factors influence the evolution of the non-performing loan rate. The impulse-response function is used to study the evolution of the dependent variable after a shock is applied to the independent variables. Thus, it was found that the depreciation in the socio-economic indicators causes the increase in the non-performing loan rate. Banks need to identify and assess the degree of risk that accompanies each loan application, and where the risk is high, it will reflect on the lending conditions (high interest rate).

The paper aims to both a statistical study and a qualitative study. The main result of the qualitative analysis is to highlight the influence of the non-performing loan rate on the capital that supports the activity of a bank. A loss arising from a non-performing loan is indirectly translated into a capital shortfall through provisions, write-offs and de-recognition. Throughout the post-crisis years, we have noticed continuous actions of recapitalization in the banking environment carried out through bail-out, bail-in, capital infusion from shareholders or new stock sales.

The motivation for the capital increases lies in the increase in the credit risk due to the nonperforming loans and the recognition of the loss, but also because of the inefficient restructuring actions.

There is an indirect influence of the credit risk ratio on capital, noting that an increase in the nonperforming loan ratio implies a higher stock of provisions specific to credit risk, being reflected by an expense in the Balance Sheet and a loss in the Income (Profit and Loss) Statement and in available capital.

The scientific novelty of the research stands in conducting a study on the operational risk in the Romanian banking system by highlighting the main aggregate indicators of the credit institutions listed on the website of the Romanian National Bank (the Central Bank of Romania). The novelty within this study is the integrative perspective of risk management techniques depending on the aggregate indicators of credit institutions and the ways to improve performance, with the purpose of highlighting the causes and the impact of the legal framework of the new prudential requirements and of various endogenous and exogenous factors on the financial results obtained by Romanian banking system overall. Moreover, I consider that there is current interest in the scientific approach stemming from the intermingling of the macro-prudential and micro-prudential levels.

The results of this study have both practical applicability and implications in macroeconomic policies, showing the effects of manifestation of non-performing loans through the deterioration of the macroeconomic environment. We believe that the effects of the deterioration of the credit portfolio of commercial banks could be reduced, given that banking prudence would be a more frequent topic on the agenda of macro-prudential regulations. Growing portfolios without a solid basis, under conditions of relaxation of lending regulations, is no longer an important endpoint in the strategy of banks, but rather a prudent growth is desired, based on well-documented rules and 
practices. Following the study developed in this article, a related analysis will consider identifying a causal relationship between the macroeconomic variables and the capital of financial institutions.

\section{REFERENCES}

Alessi, M., Di Colli, S. \& Lopez, J.S. (2014). Loan Loss Provisioning and Relationship Banking in Italy: Practices and Empirical Evidence, Journal of Entrepreneurial and Organizational Diversity, 3(1), 111-129.

Arestis, P., \& Jia, M.M. (2019). Credit risk and macroeconomic stress tests in China. Journal of Banking Regulation, 20(3), 211-225. London, UK: Palgrave Macmillan. Doi: https://doi.org/10.1057/s41261-018-0084-1. Retrieved on May 20, 2020, from: https://ideas.repec.org/a/pal/jbkreg/v20y2019i3d10.1057_s41261-018-0084-1.html

Buch, C., Eickmeier, S. \& Prieto, E. (2014) Macroeconomic Factors and Microlevel Bank Behavior, Journal of Money, Credit and Banking, 46( 4), 715-751.

Bunn, P. \& Redwood, V. (2003). Company accounts based modelling of business failures and the implications for financial stability. Bank of England working papers no. 210. Retrieved on July 30, 2020, from: https://papers.ssrn.com/sol3/papers.cfm?abstract id=598276

Castro, V. (2013). Macroeconomic determinants of the credit risk in the banking system: The case of the GIPSI, Economic Modelling, 31, 672 -683.

Dash, M. K. \& Kabra, G. (2010). The Determinants of Nonperforming Assets in Indian Commercial Banks: An Econometric Study. Middle Eastern Finance and Economics. 7 (2), 94-106.

Derbali, A. (2011) Determinants of Banking Profitability Before and During the Financial Crisis of 2007: The Case of Tunisian Banks, Interdisciplinary Journal of Contemporary Research in Business (3), 1256-1269.

Espinoza, R. \& Prasad, A. (2010). Nonperforming Loans in the GCC Banking Systems and their Macroeconomic Effects. IMF Working Paper WP/10/224. Retrieved on July 26, 2020, from: https://www.imf.org/external/pubs/ft/wp/2010/wp10224.pdf

Fofack, H. (2005). Nonperforming loans in Sub-Saharan Africa: causal analysis and macroeconomic implications. World Bank Policy Research Working Paper No. 3769. Retrieved on July 25, 2020, from: http://papers.ssrn.com/sol3/papers. cfm?abstract_id=849405

Figlewski, S., Frydman, H. \& Liang, W. (2012). Modelling the Effect of Macroeconomic Factors on Corporate Default and Credit Rating Transitions, International Review of Economics and Finance (21), 87-105. http://dx.doi.org/10.1016/j.iref.2011.05.004

Klein, N. (2013). Non-Performing loans in CESEE: determinants and impact on macroeconomic performance. International Monetary Fund Working Paper WP/13/72, Retrieved on June 05, 2020, from: http://www.imf.org/external/pubs/ ft/wp/2013/wp1372.pdf

Koju, L., Koju, R. \& Wang, S. (2019), Macroeconomic determinants of credit risks: evidence from high-income countries, European Journal of Management and Business Economics, 29(1), 4153. https://doi.org/10.1108/EJMBE-02-2018-0032

Johnson, A.M., Boehlje, M.D. \& Gunderson, M. (2017). Agricultural credit risk and the macroeconomy: Determinants of Farm Credit Mid-America PD migrations, Agricultural Finance Review, 77(1), 164-180.

Louzis, D.P., Vouldis, A.T. \& Metaxas, V.L. (2012). Macroeconomic and bank-specific determinants of non-performing loans in Greece: a comparative study of mortgage, business and consumer loan portfolios. Journal of Banking \& Finance, 36 (2012), 1012-1027. Retrieved on June 10, 2020, from: https://isiarticles.com/bundles/Article/pre/pdf/5907.pdf

Makri, V. \& Papadatos, K. (2016). Determinants of Loan Quality: Lessons from Greek Cooperative Banks, Review of Economic \& Business Studies, 9(1), 115-140.

Makri, V., Tsagkanos, A., \& Bellas A. (2014). Determinants of Non-Performing Loans: the case of Eurozone, Panoeconomicus, 61 (2), 193-206. 
Mcwayizeni Thwala, C. (2016). The sensitivity of bank credit risk indicators to macroeconomic variables. A dissertation submitted to the Faculty of Commerce, Law and Management University of the Witwatersrand Business School, Johannesburg. Retrieved on August 15, 2020, from: https://core.ac.uk/download/pdf/188775999.pdf

Moinescu, B. \& Codirlaşu, A. (2013). Lending, economic growth and nonperforming loans: empirical evidences from the new EU member states. Working Paper, Project "PN-II-ID-PCE2011-3-1054 - Uncertainty, Complexity and Financial Stability“, Retrieved on August 15, 2020, from: http://finsys.rau.ro/docs/wp-lending economic growth.pdf

Skała, D. (2014). Credit policy in small Polish banks - is there room for income smoothing? Collegium of Economic Analysis Annals, Warsaw School of Economics, 34, 183-196.

Virolainen, K. (2004). Macro Stress Testing with a Macroeconomic Credit Risk Model for Finland, Bank of Finland Discussion Paper No. 18/2004. Retrieved on August 12, 2020, from: https://papers.ssrn.com/sol3/papers.cfm?abstract id $=622682$

Zheng, Ch., Sarker, N., \& Nahar, Sh. (2018). Journal of Applied Finance \& Banking, 8(2), 45-67. 